\title{
In vivo assessment of bone marrow toxicity by gold nanoparticle-based bioconjugates in Crl:CDI (ICR) mice
}

This article was published in the following Dove Press journal:

International Journal of Nanomedicine

I September 2016

Number of times this article has been viewed

\section{Cristian Berce ${ }^{1, *}$ \\ Ciprian Lucan ${ }^{2, *}$ \\ Bobe Petrushev 3,4 \\ Sanda Boca $^{5}$ \\ Mirela Miclean ${ }^{6}$ \\ Orsolya Sarpataki ${ }^{7}$ \\ Simion Astilean ${ }^{5}$ \\ Anca Buzoianu ${ }^{8}$ \\ Ciprian Tomuleasa ${ }^{3,9}$ \\ Anca Bojan 9,10 \\ 'Animal Facility, ${ }^{2}$ Department of Surgery, ${ }^{3}$ Research Center for Functional Genomics and Translational Medicine, ${ }^{4}$ Department of Pathology, Iuliu Hatieganu University of Medicine and Pharmacy, ${ }^{5}$ Nanobiophotonics and Laser Microscopy Center, Interdisciplinary Research in Bio- Nano-Sciences - Faculty of Physics, Babes-Bolyai University, ${ }^{6}$ Institute for Research in Analytical Instruments, ${ }^{7}$ Department of Pathophysiology, University of Veterinary Medicine, ${ }^{8}$ Department of Pharmacology, luliu Hatieganu University of Medicine and Pharmacy, ${ }^{9}$ Department of Hematology, Ion Chiricuta Oncology Institute, ${ }^{10}$ Department of Hematology, luliu Hatieganu University of Medicine and Pharmacy, Cluj Napoca, Romania}

*These authors contributed equally to this work

Correspondence: Ciprian Tomuleasa Department of Hematology, Ion Chiricuta Oncology Institute, Strada Gheorghe Marinescu No 23, Cluj Napoca 400000, Romania Tel +40 74I337480 Email ciprian.tomuleasa@umfcluj.ro
Introduction: The present study aimed at evaluating the biodistribution of Tween ${ }^{\circledR} 20$-gold nanoparticle (GNP) conjugates and their potential toxicity on the bone marrow before moving on to Phase I clinical trials.

Materials and methods: Tween ${ }^{\circledR} 20$-conjugated GNPs were injected intravenously for 21 days in male Crl:CD1(ICR) mice. Body weight of the mice was evaluated each day. After the sub-chronic Tween ${ }^{\circledR}$ 20-GNPs administration, blood samples were harvested, and a full blood count was done individually. Total Au quantity from all major organs was assessed using inductively coupled plasma mass spectrometry. One femur and the sternum obtained from each animal were used for histological assessment.

Results: Our data showed that the Tween ${ }^{\circledR} 20$-GNP conjugates were found in large quantities in the bladder. Au was shown to accumulate in the hematopoietic bone tissue, with significant side effects such as leucopoiesis and megakaryopoiesis. The mice had a higher white blood cell and platelet count as opposed to the control group. This suggested that the previously described leukopenic effects of isoflurane were overridden by the leucopoietic effects of Tween ${ }^{\circledR}$ 20-GNPs.

Conclusion: It was uncertain whether the mice were reactive to $\mathrm{Au}$ as it is a foreign substance to the tissues or whether the side effects observed were a precursor condition of a more severe hematological condition. Au was found to be hepatotoxic, urging the need for further studies in order to achieve better in vivo compliance and exploit the immense potential of GNPs in cancer pharmacology.

Keywords: GNPs, Tween ${ }^{\circledR} 20$, in vivo toxicology

\section{Introduction}

Recent advances in nanotechnology have brought in the last few years various options that could be used in the clinic by using constructs for cytostatic drug delivery, nanoscale immunotherapy, disease detection, and molecular diagnosis. ${ }^{1-4}$ Progress in nanotechnology has brought to the attention of clinicians new ways of treating cancer as the major purpose is the use of nanoscale drug delivery system in order to improve the therapeutic index of a patient diagnosed with cancer. This can be achieved by increasing the concentration of an anticancer drug in the tumor while reducing its systemic toxicity. ${ }^{5-7}$ The US Food and Drug Administration has approved for cancer therapy the use of doxorubicin encapsulated in liposomes (Doxil) and paclitaxel attached to nanoparticles (Abraxane). ${ }^{8,9}$ In cancer chemotherapy, the clinician aims to achieve a good therapeutic index, which is the ratio of the lethal dose for $50 \%$ of the population to the minimum effective dose for $50 \%$ of the population. ${ }^{10}$ But cancer is most often 
characterized by multidrug resistance, and thus, scientists have developed new ways to target the drug-resistant cancer cells, in most of the cases hypoxic or distant from any blood supply, by overcoming the natural barrier of drug efflux pump. The smart molecules developed by scientists may increase the bioavailability of an active agent and change it from a candidate with a low therapeutic value into a highly efficient medicine. As we have proven before that gold nanoparticles (GNPs) can successfully increase the efficacy of various anticancer drugs in vitro, ${ }^{11-13}$ in the current paper, we aimed at investigating the biodistribution of GNP-based bioconjugates, as well as to assess their potential toxicity on the bone marrow in order to move on toward more complex preclinical experiments on animal models of the disease.

\section{Materials and methods Materials}

Hydrogen tetrachloroaurate (III) hydrate $\left(\mathrm{HAuCl}_{4} \cdot 3 \mathrm{H}_{2} \mathrm{O}\right.$, $99.99 \%)$, trisodium citrate $\left(\mathrm{C}_{6} \mathrm{H}_{5} \mathrm{Na}_{3} \mathrm{O}_{7}\right)$, and Tween ${ }^{\circledR} 20$ (polyethylene glycol sorbitan monolaurate) were purchased from Sigma-Aldrich Co. (St Louis, MO, USA). Ultrapure water was used in all rinsing procedures.

\section{Nanoparticle preparation}

Tween $^{\circledR} 20$-conjugated GNPs were prepared using a protocol described by Duy et al. ${ }^{14}$ The particles were purified by fast-speed centrifugation and resuspension in isotonic serum. Another step of centrifugation was applied to concentrate the particles until they reached a density of $385 \mu \mathrm{g}$ gold $(\mathrm{Au}) / \mathrm{mL}$.

\section{Characterization of Tween ${ }^{\circledR}$ 20-conjugated GNPs}

Tween ${ }^{\circledR} 20$-conjugated GNPs were characterized by several analysis methods including UV-vis absorption spectroscopy, dynamic light scattering (DLS), and zeta potential determination. Absorption spectra of the colloidal nanoparticles were obtained using a Jasco V-670 UV-Vis-NIR spectrometer (Jasco Inc., Easton, MD, USA). Analysis of particle size distribution by DLS and that of zeta potential was performed using the Zetasizer NanoZS90 instrument from Malvern Instruments (Malvern, UK). Transmission electron microscopy images of GNPs were obtained using a JEOL model JEM1010 microscope (JEOL, Tokyo, Japan).

\section{Animals and housing}

Twenty $(\mathrm{n}=20)$ male $\mathrm{Crl}$ :CD1(ICR) mice with a median weight of $27.79 \pm 0.2487 \mathrm{~g}$ (mean \pm 1.084 standard deviation [SD]) were used in the present study. The animals were housed in polysulfone type II-L open-top cages (Tecniplast,
Buguggiate, Italy) and had access to filtered tap water in bottles and pelleted feed (Cantacuzino Institute, Bucharest, Romania) ad libitum. The bedding was a standard wood chip aseptic bedding (Lignocel ${ }^{\circledR}$; J. Rettenmaier \& Söhne $\mathrm{GmBH}+\mathrm{Co}$. KG, Rosenberg, Germany). The mice were bred and kept in the Laboratory Animal Facility of the Iuliu Hatieganu University of Medicine and Pharmacy at a standard temperature of $22^{\circ} \mathrm{C} \pm 2^{\circ} \mathrm{C}$ and a relative humidity of $55 \% \pm 10 \%$, in a 12:12-hour light:dark cycle (lights on, 7 am to $7 \mathrm{pm}$ ) at a light intensity of $300 \mathrm{~lx}$ at $1 \mathrm{~m}$ above the floor, and were allocated into two groups: group $A(n=10$; experimental group) and group $\mathrm{B}(\mathrm{n}=10$; control group). The groups were randomized in different cages, and the individuals were numbered on the base of their tail using permanent makers (Sharpie, Oak Brook, IL, USA) from 1 to 20. All experimental protocols were approved by the Ethics Committee of Iuliu Hatieganu University of Medicine and Pharmacy and were conducted in accordance with the EU Directive 63/2010. Prior to the onset of the study, all animals were quarantined and left to acclimatize to the separation from the mice colony for 10 days. For environmental enrichment, autoclaved braided cotton dental rolls were used (Celluron ${ }^{\circledR}$; Hartmann, Heidenhelm, Germany), as previously described. ${ }^{15,16}$ The study was designed and performed in accordance with the ARRIVE Guidelines for Reporting Animal Research. ${ }^{17}$ All animal-handling procedures were performed according to the European and Romanian guidelines.

\section{Acute toxicity assessment}

The animals were subjected to an acute toxicity test carried out according to the Acute Toxic Class Method of OECD. The individuals were randomly assigned into ten groups: one control group that did not receive any treatment and nine experimental groups which received the GNP + Tween ${ }^{\circledR} 20$ conjugate at dosages of 100, 250, 500, 750, 1,000, $1,250,1,500,1,750$, and $2,000 \mu \mathrm{g} / \mathrm{kg}$ of body weight. The GNP + Tween ${ }^{\circledR} 20$ conjugate was administered parenterally using the retro-orbital injection method described by Yardeni et al. ${ }^{18}$ For the intravenous (iv) injections, $1 \mathrm{~mL}$ syringes with $27 \mathrm{G}$ needles were used (BD, Franklin Lakes, NJ, USA). The mice from both groups were anesthetized with isoflurane (Aerrane, Baxter, UK) using a standard vaporizer (EZ-Anesthesia ${ }^{\circledR}$; E-Z Systems, Palmer, PA, USA) during the injection procedure. Fourteen days after the single-dose administration, blood was collected using the retro-orbital collection method for hematological assessment. The humane end point of the experiment required the euthanasia of all animals using the cervical dislocation method and harvesting all major organs (heart, lungs, spleen, liver, kidneys). 
The organs were weighed and preserved for histological evaluation in formaldehyde. All experimental protocols were approved by the Ethics Committee of the University and were conducted in accordance with the EU Directive 63/2010. The animals were observed daily by the designated veterinarian for clinical and behavioral changes.

\section{Procedure and data collection}

The Tween ${ }^{\circledR} 20$-GNPs solution was filtered using a $1 \mu \mathrm{m}$ hydrophobic polytetrafluoroethylene membrane syringe filter (Merck Millipore, Billerica, MA, USA) to remove any debris and microbiological impurities and was kept in a refrigerator. For the iv injections, $1 \mathrm{~mL}$ insulin was injected using $27 \mathrm{G}$ needle syringes (BD). The mice from both groups were anesthetized with isoflurane (Aerrane) using a standard vaporizer (EZ-Anesthesia ${ }^{\circledR}$; E-Z Systems). Group A had received daily iv injections with the Tween ${ }^{\circledR} 20$-GNPs solution $(1,100 \mu \mathrm{g} / \mathrm{kg})$ for 21 days using the retro-orbital injection method, while group B received daily iv injections with isotonic saline. The injection sites (retro-orbital sinuses) were changed each day in order to avoid scar tissue formation. Body weight of all individuals was recorded daily. After 21 days, blood samples were harvested using the retro-orbital collection method, and a full blood count was done for each individual using a veterinary-grade hematological analyzer (Abacus Junior Vet; Diatron, Budapest, Hungary). The end point of the study was the euthanasia of all animals from both groups using the cervical dislocation method, followed by the harvesting of all major internal organs after autopsy (brain, heart, lungs, liver, spleen, kidneys, and urinary bladder as well as the femurs and sternums). The quantities of $\mathrm{Au}$ from all of these organs were assessed using inductively coupled plasma mass spectrometry (ICP-MS) (Perkin-Elmer Elan DRC II; PerkinElmer Inc., Waltham, MA, USA). One femur and the sternum from each animal were used for histological assessment. The levels of aspartate aminotransferase, alanine aminotransferase, and bilirubin were assessed using a spectrophotometer (StatFax 1904 Chemistry Analyzer; GMI Inc., Ramsey, MN, USA).

\section{Inductively coupled plasma mass spectrometry}

Tissue sample digestion was performed according to the method described by Sadauskas et al. ${ }^{19}$ Briefly, samples were digested with $5 \mathrm{~mL}$ of $65 \%$ nitric acid, $0.5 \mathrm{~mL}$ of $30 \%$ hydrogen peroxide, and $1 \mathrm{~mL}$ hydrochloric acid in a microwave oven (Speedwave; Berghof, Eningen, Germany). All the reagents were of PA grade (EMD Millipore, Billerica, MA, USA). For measurements of Au, a Perkin-Elmer Elan
DRC II (PerkinElmer Inc.) inductively coupled plasma mass spectrometer was used. The dynamic reaction cell was used in radiofrequency-only mode, and a quantitative method was developed for measuring Au concentration in liquid samples. After a semiquantitative run to assess the Au content, the calibration curve covered the interval from 1 to $50(1,5,10$, and $50 \mu \mathrm{g} / \mathrm{L}$ ) to ensure that concentration of all the samples fits the chosen range without dilution.

\section{Histological assessment}

The femurs, sternums, and liver samples were dissected and fixed for 24 hours in 4\% paraformaldehyde (Sigma-Aldrich Co.). Bone decalcification was achieved by immersing the samples in $15 \%$ ethylenediamine tetraacetic acid (SigmaAldrich Co.) for 10 days at $4^{\circ} \mathrm{C}$. The decalcified bone and liver specimens were then dehydrated using a tissue processor (Leica TP1020; Leica Microsystems, Wetzlar, Germany) and embedded in paraffin according to the standard procedure. Longitudinal $8 \mu \mathrm{m}$-thick sections were obtained, collected on microscope slides (Thermo Fisher Scientific, Waltham, MA, USA), and stained with hematoxylin-eosin. The histological assessment was done using an Olympus BX46 microscope (Olympus Corporation, Tokyo, Japan).

\section{Statistical analysis}

The obtained data were analyzed using two statistical software packages (GraphPad Prism 5.0 and R; GraphPad Software, Inc., La Jolla, CA, USA). The data were initially analyzed by using the Shapiro-Wilk test to determine whether the distribution was normal. Comparisons of absolute values of the body weight variables of the two groups at each time point over the 21-day study period were performed by using an independent-samples $t$-test when the two samples had equal variances or by using the Welch $t$-test when the two samples had unequal variances. The final body weight data were analyzed using the two-way analysis of variance Bonferroni test. The ICP-MS data were analyzed by determining the mean, standard error of the mean, and standard deviation using a $95 \%$ confidence interval. The level of statistical significance was between $* P<0.05$ and $* * * P<0.01$.

\section{Results}

\section{Characterization of Tween ${ }^{\circledR}$ 20-GNPs}

A first characterization of Tween ${ }^{\circledR} 20$-conjugated GNPs was done by measuring the optical response of the particles by UV-vis absorption spectroscopy. Figure 1 presents the UV-vis absorption spectrum of Tween ${ }^{\circledR} 20$-conjugated nanoparticles in serum (red spectrum) together with the absorption spectrum of the uncoated control nanoparticles 


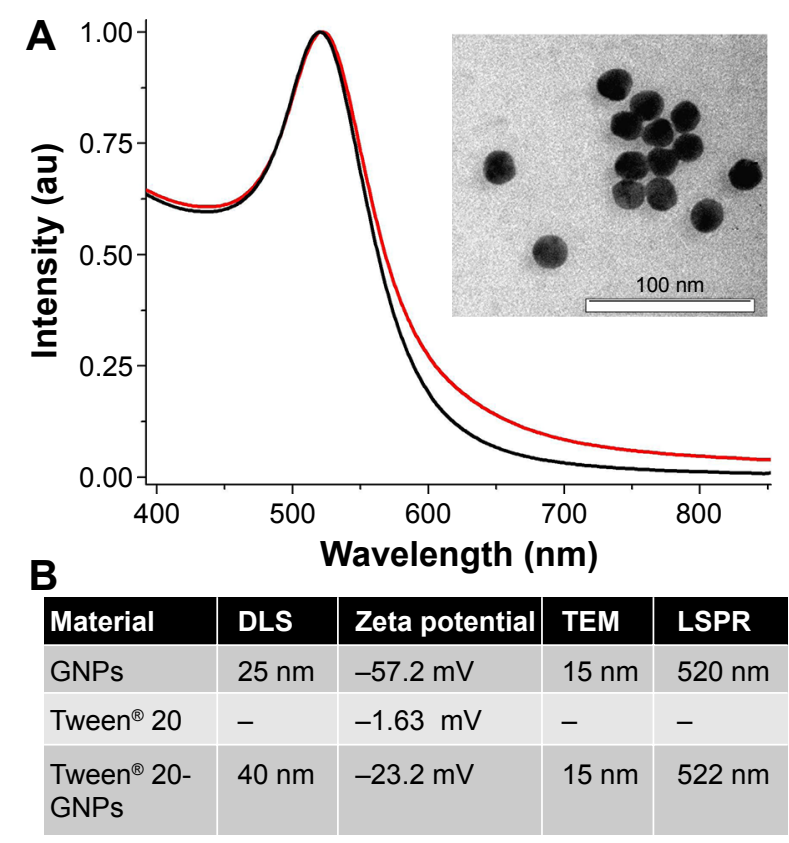

Figure I Physical characterization of the nanostructures.

Notes: (A) UV-vis absorption spectra of gold nanoparticles (black spectrum) and Tween ${ }^{\circledR} 20$-coated GNPs (red spectrum). The spectra are normalized to unity for better illustration. Inset: TEM image of gold nanoparticles. (B) Shows assigned values of nanoparticle hydrodynamic diameter determined by DLS, zeta potential, diameter determined by TEM, and LSPR band position. "--" indicates no data.

Abbreviations: GNPs, gold nanoparticles; TEM, transmission electron microscopy; DLS, dynamic light scattering; LSPR, localized surface plasmon resonance; au, arbitrary units; UV, ultra violet.

(black spectrum) which is illustrated for comparison purpose. The plasmonic band situated at $520 \mathrm{~nm}$ is a characteristic of spherical GNPs of a mean size of $20 \mathrm{~nm}$ which was verified and correlated with the transmission electron microscopy image shown in Figure 1 (inset), and also with the DLS measurements. From the spectra, we observe that for Tween ${ }^{\circledR} 20$-GNPs, the plasmonic band is red shifted at several nanometers. This occurs as a result of the refractive index change after the particles bind with $\operatorname{Tween}^{\circledR} 20$. Overall, the spectrum of conjugated particles is quite similar to that of the uncoated nanoparticles, which proves the high stability of the Tween ${ }^{\circledR} 20$-conjugated nanoparticles in serum. The increased values of the particle hydrodynamic diameter measured by DLS (table in Figure 1) together with the modification of the particle surface charge after the addition of Tween ${ }^{\circledR} 20$ surfactant (table in Figure 1) corroborate with the spectroscopic results and prove the efficient conjugation of the particles by Tween ${ }^{\circledR} 20$.

\section{Acute toxicity results}

Acute toxicity studies are very important tools for the assessment of a newly synthesized molecule that has been previously proven effective in vitro. In vivo studies allow an evaluation of the safety profile of the new molecule and provide important information required for further biological studies such as sub-chronic and chronic toxicity tests. We assessed the acute toxicity of a GNP + Tween ${ }^{\circledR} 20$ conjugate using healthy mice in order to remove any possibility of error caused by an occult inflammatory process.

The tested substance was well tolerated at all dose levels after the iv administration, and all animals survived. The substance did not cause any severe clinical or behavioral alterations such as aggressiveness, tremors, convulsions, respiratory distress, dizziness, lethargy, sleep, or coma. There were no changes of statistical significance in body weight in the control group as opposed to the experimental group. The complete comprehensive data are shown in Tables 1-3

Table I The body weight evaluation for various doses of Tween ${ }^{\circledR} 20-$ GNPs at days I-I4

\begin{tabular}{|c|c|c|c|c|c|c|c|c|c|c|}
\hline \multirow[t]{2}{*}{ Day } & \multicolumn{10}{|c|}{ Dosage $(\mu \mathrm{g})$} \\
\hline & 0 & 100 & 250 & 500 & 750 & 1,000 & 1,250 & 1,500 & $\mathrm{I}, 750$ & 2,000 \\
\hline I & $27.5( \pm 0.5)$ & $27( \pm 0.5)$ & $29.5( \pm 0.5)$ & $29( \pm \mathrm{I} .5)$ & $28.5( \pm 0.5)$ & $28.5( \pm 0.5)$ & $28.5( \pm 0.5)$ & $28( \pm \mathrm{I} .5)$ & $29.5( \pm 0.5)$ & $29.5( \pm 0.5)$ \\
\hline 2 & $27.5( \pm 0.5)$ & $27( \pm 0.5)$ & $29.5( \pm 0.5)$ & $28( \pm 0.5)$ & $29.5( \pm 0.5)$ & $30.5( \pm 0.5)$ & $29.5( \pm 0.5)$ & $29.5( \pm 0.5)$ & $29.5( \pm 0.5)$ & $29.5( \pm 0.5)$ \\
\hline 3 & $28( \pm I)$ & $27.5( \pm \mathrm{I} .5)$ & $29( \pm 1.5)$ & $29.5( \pm \mathrm{I} .0)$ & $29( \pm 1.5)$ & $29( \pm 0.5)$ & $29( \pm \mathrm{I} .5)$ & $28.5( \pm \mathrm{I} .5)$ & $30( \pm 0.5)$ & $29( \pm \mathrm{I} .5)$ \\
\hline 4 & $28.5( \pm 1.5)$ & $28( \pm 0.5)$ & $29( \pm 1.5)$ & $28( \pm 1.5)$ & $29( \pm 0.5)$ & $29( \pm 0.5)$ & $29( \pm I .5)$ & $29( \pm 0.5)$ & $29( \pm 0.5)$ & $28.5( \pm 0.5)$ \\
\hline 5 & $28.5( \pm \mathrm{I} .5)$ & $28.5( \pm I)$ & $28.5( \pm 0.5)$ & $27.5( \pm 0.5)$ & $28( \pm 0.5)$ & $29( \pm 0.5)$ & $30( \pm 0.5)$ & $29( \pm 0.5)$ & $29( \pm I .5)$ & $29( \pm 0.5)$ \\
\hline 6 & $28.5( \pm I .5)$ & $28( \pm 0.5)$ & $29( \pm 0.5)$ & $30( \pm I .5)$ & $29( \pm 0.5)$ & $28( \pm I)$ & $29( \pm 1.5)$ & $29( \pm 1.5)$ & $29( \pm 1.5)$ & $29( \pm 1.0)$ \\
\hline 7 & $30.5( \pm 0.5)$ & $30.5( \pm 0.5)$ & $30.5( \pm I .5)$ & $30.5( \pm 0.5)$ & $30.5( \pm 0.5)$ & $27.5( \pm 0.5)$ & $30.5( \pm 0.5)$ & $29.5( \pm 0.5)$ & $30( \pm 0.5)$ & $30.5( \pm 0.5)$ \\
\hline 8 & $30( \pm 0.5)$ & $30( \pm 1.5)$ & $29.5( \pm 0.5)$ & $29.5( \pm 0.5)$ & $29( \pm 1.5)$ & $29( \pm 0.5)$ & $29( \pm 0.5)$ & $29( \pm I .5)$ & $29( \pm 0.5)$ & $29( \pm 0.5)$ \\
\hline 9 & $29( \pm 0.5)$ & $29( \pm 0.5)$ & $29( \pm \mathrm{I})$ & $29( \pm I .5)$ & $28.5( \pm 0.5)$ & $29( \pm 0.5)$ & $29( \pm 0.5)$ & $28( \pm I .0)$ & $29( \pm I .5)$ & $27.5( \pm 1.0)$ \\
\hline 10 & $30.5( \pm 1.5)$ & $30.5( \pm 0.5)$ & $30( \pm 0.5)$ & $30.5( \pm 0.5)$ & $30( \pm 0.5)$ & $30( \pm I .5)$ & $28.5( \pm 0.5)$ & $30( \pm 0.5)$ & $30( \pm I .0)$ & $30( \pm 0.5)$ \\
\hline 11 & $29( \pm 1.5)$ & $29( \pm 1.5)$ & $28.5( \pm 0.5)$ & $28.5( \pm 0.5)$ & $28.5( \pm 0.5)$ & $29.5( \pm 1.0)$ & $29( \pm 0.5)$ & $29.5( \pm 0.5)$ & $29.5( \pm 0.5)$ & $27.5( \pm 1.5)$ \\
\hline 12 & $30.5( \pm 0.5)$ & $29( \pm 0.5)$ & $30( \pm I)$ & $29( \pm I)$ & $28.5( \pm 0.5)$ & $29( \pm 0.5)$ & $29( \pm 1.5)$ & $28(1.5)$ & $29( \pm 0.5)$ & $27.5( \pm 0.5)$ \\
\hline 13 & $31( \pm 0.5)$ & $30( \pm 0.5)$ & $28.5( \pm 0.5)$ & $30( \pm I .5)$ & $30( \pm I .5)$ & $30( \pm \mid .5)$ & $28.5( \pm 0.5)$ & $30( \pm 0.5)$ & $30( \pm 0.5)$ & $30( \pm 0.5)$ \\
\hline 14 & $31.5( \pm 0.5)$ & $29.5( \pm I .5)$ & $28.5( \pm I .5)$ & $29( \pm I)$ & $28.5( \pm 1.0)$ & $29.5( \pm 0.5)$ & $29( \pm 0.5)$ & $29.5( \pm 0.5)$ & $29.5( \pm 0.5)$ & $27.5( \pm 1.5)$ \\
\hline
\end{tabular}

Note: Data are presented as mean $( \pm$ SEM).

Abbreviations: GNPs, gold nanoparticles; SEM, standard error of the mean. 


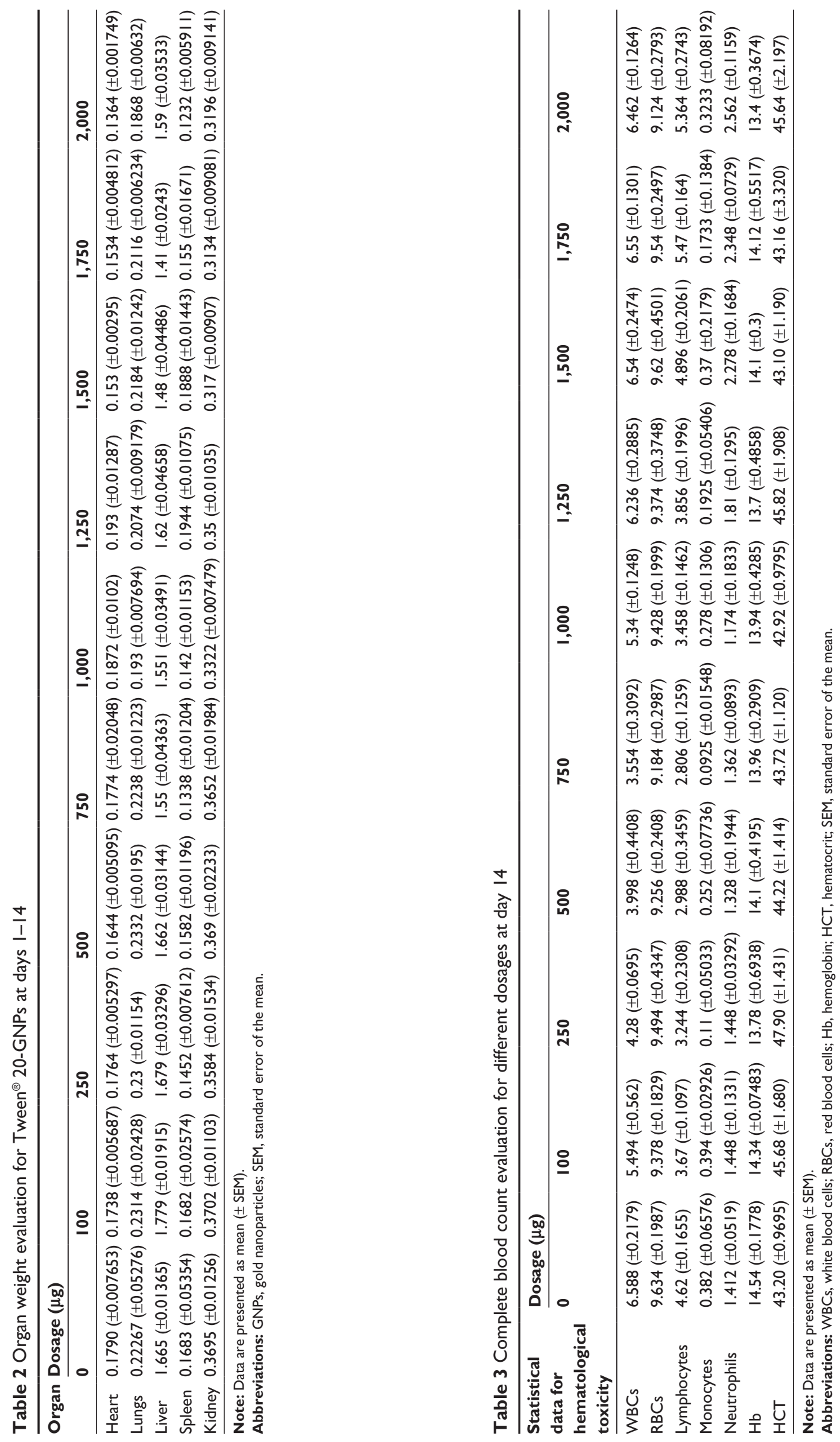


and Figures $2 \mathrm{~A}-\mathrm{E}$ and $3 \mathrm{~A}-\mathrm{G}$. The organ weight evaluation is shown in Figure $2 \mathrm{~A}-\mathrm{E}$. The hematological analyses are shown in Figure 3A-G. After these extensive acute toxicity tests, we chose a dosage of $1,100 \mu \mathrm{g} / \mathrm{kg}$. The pathology examination of the organs showed no degenerative, inflammatory, vascular, necrotic, or apoptotic lesions, as seen in Figure $4 \mathrm{~A}-\mathrm{E}$.

\section{Toxicology assessment}

After 21 days of Tween ${ }^{\circledR} 20-$ GNPs systemic administration, we identified an increase in body weight in the experimental group (group A) as opposed to the control group (group B). The mean body weight of group A was $33.27 \pm 0.4066 \mathrm{~g}$, while the mean body weight of group B was $31.50 \pm 0.7071 \mathrm{~g}$. The interaction accounted for $7.75 \%$ of the total variance, which was highly statistically significant $(P<0.0001)$. The time accounted for $24.65 \%$ of the total variance, after adjusting and matching $(P<0.0001)$, while the treatment accounted only for $0.86 \%$ of the total variance $(P=0.5194)$ (Table 4 and Figure 5). A total of eight hematological parameters were measured in the present study. The total white blood cell (WBC) and lymphocyte counts were below the standard
A

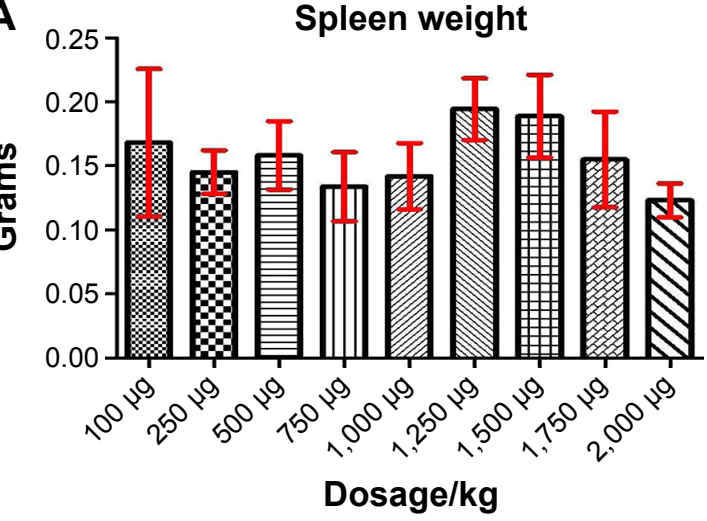

C

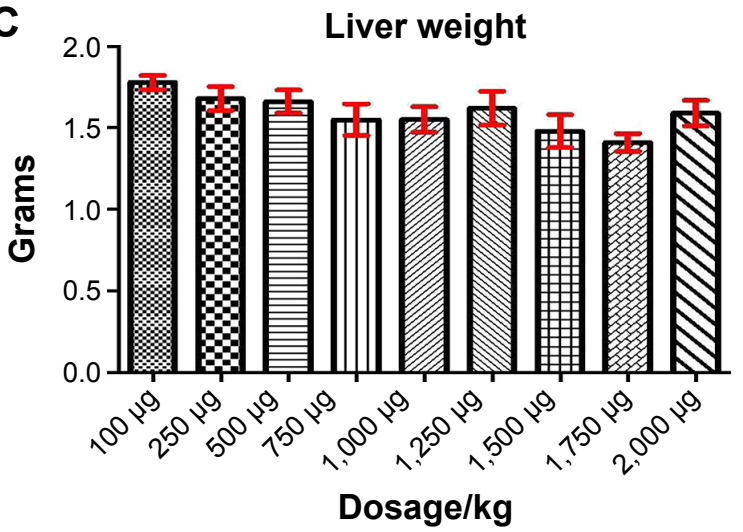

B $0.3 \quad$ Lung weight
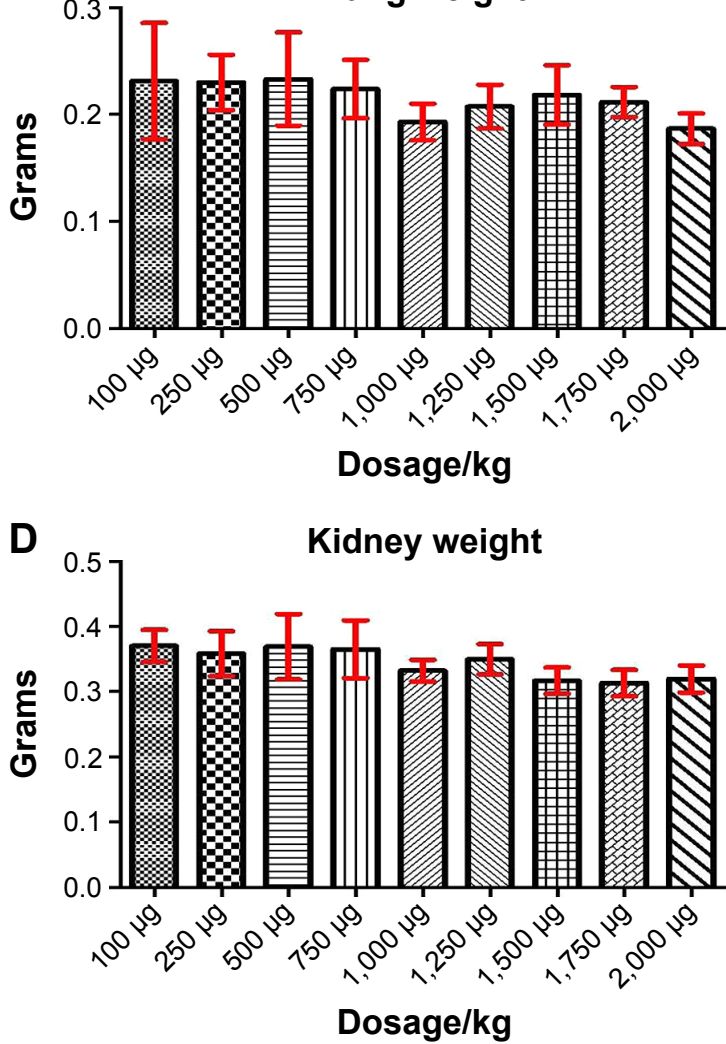

E

Heart weight

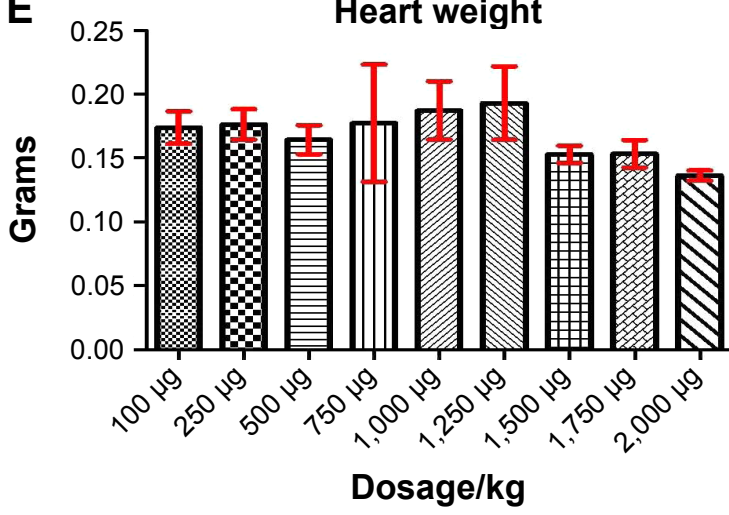

Figure 2 Organ weight evaluation for the acute toxicity experiments, for different nanoparticle concentrations. Notes: Evaluation for the spleen (A), lung (B), liver (C), kidney (D), and heart (E). 
A

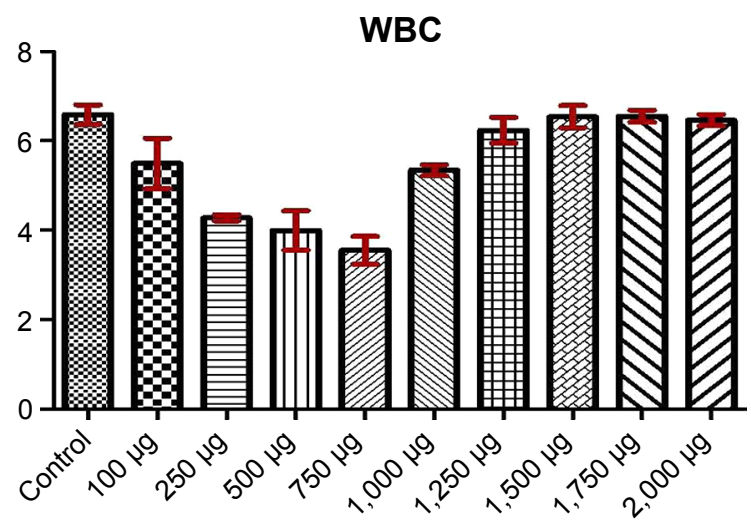

C

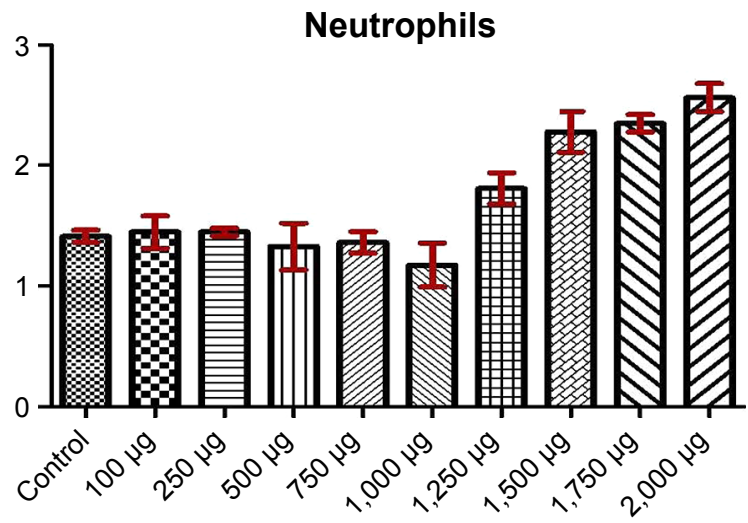

E

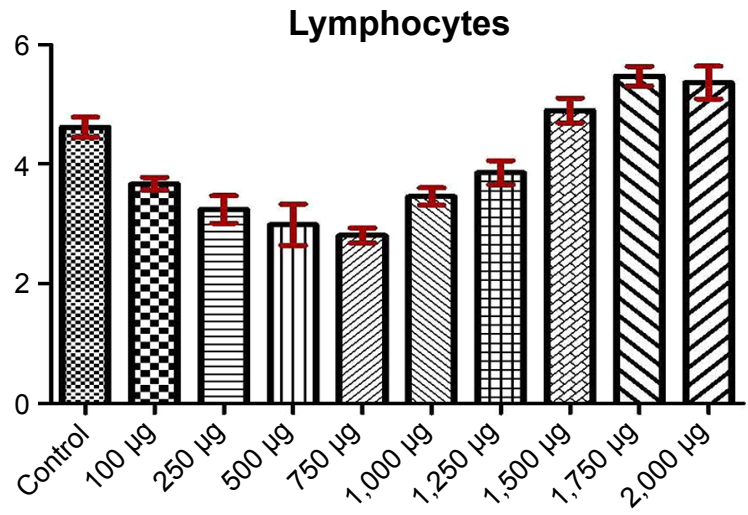

B

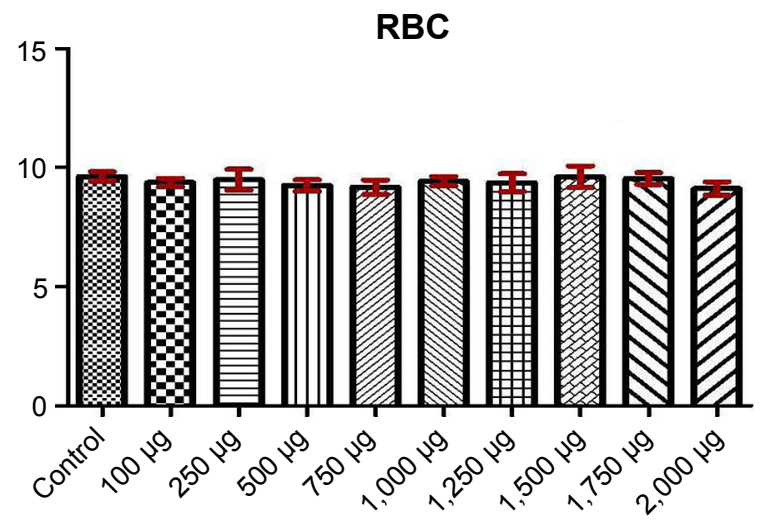

D

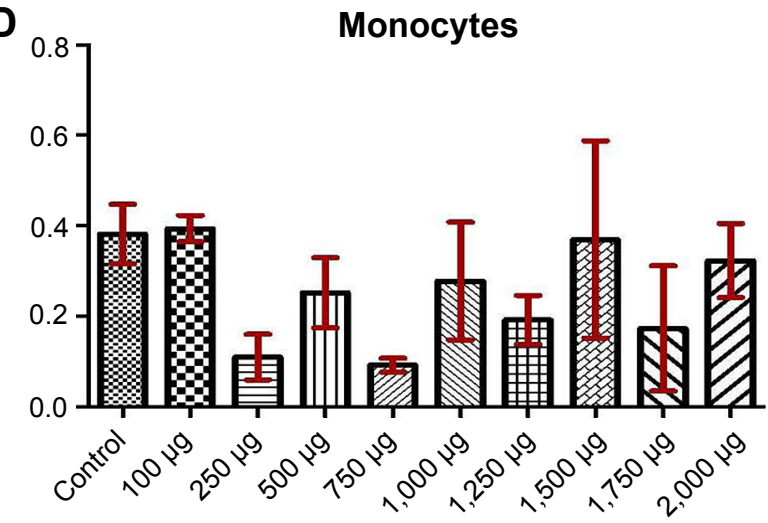

$\mathbf{F}$

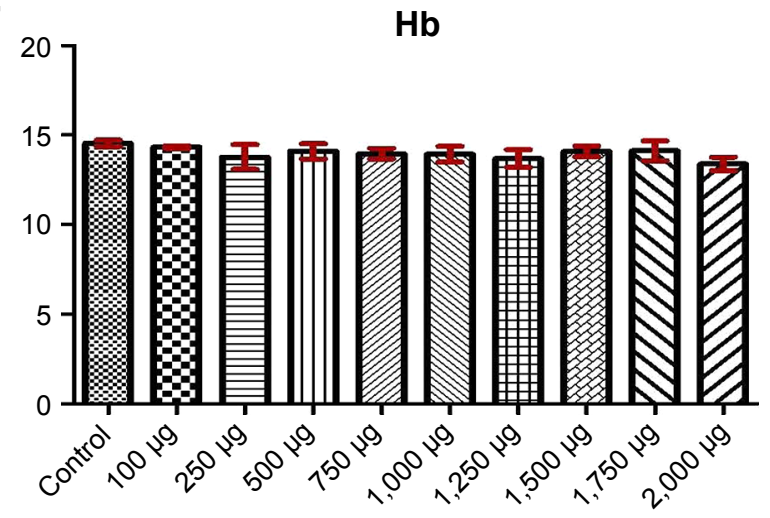

G

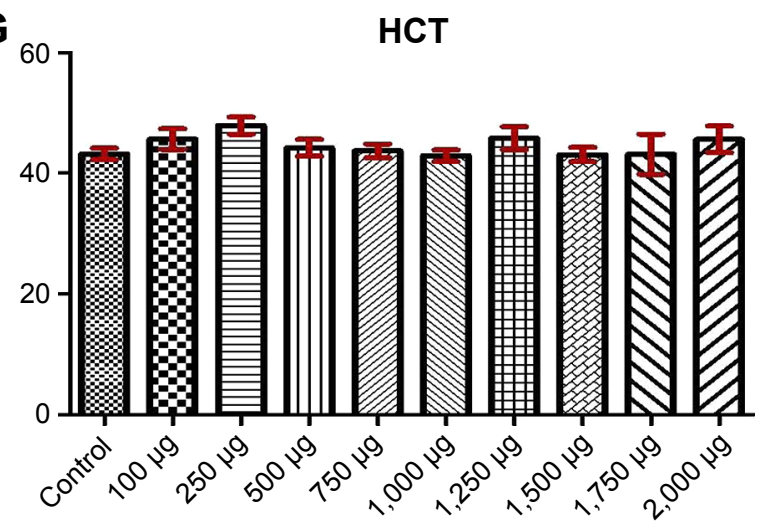

Figure 3 Hematological assessment at day 14.

Notes: WBC count (A), RBC count (B), neutrophil count (C), monocyte count (D), lymphocyte count (E), Hb value (F), and HCT value (G).

Abbreviations: WBC, white blood cell; RBC, red blood cell; Hb, hemoglobin; $\mathrm{HCT}$, hematocrit. 

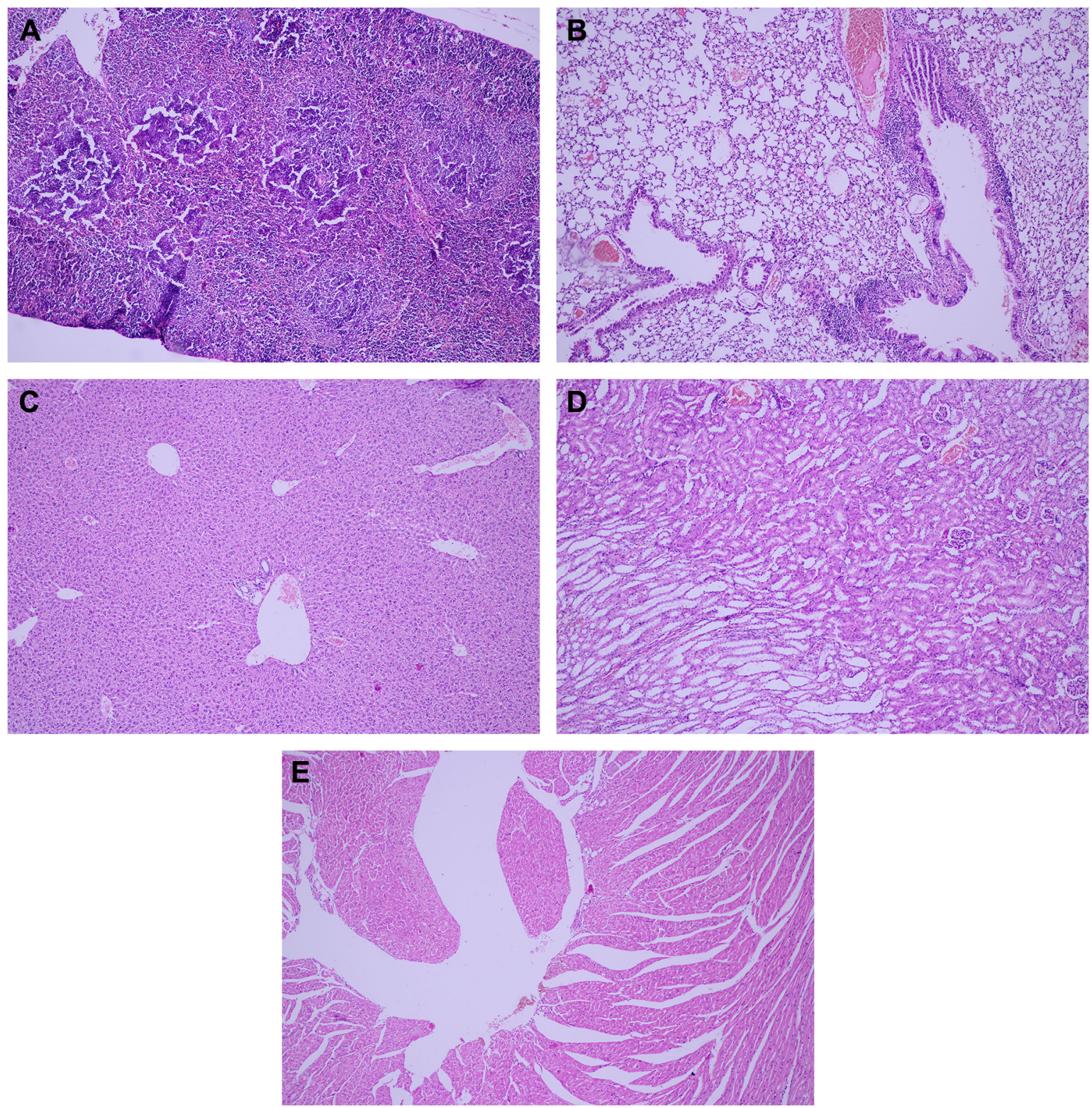

Figure 4 Pathology examination of the organs.

Notes: No acute toxicity of the Tween ${ }^{\circledR} 20$-GNPs construct over the spleen (A), lung (B), liver (C), kidney (D), and heart (E). $\times 20$ magnification.

Abbreviation: GNPs, gold nanoparticles.

physiological values in both groups, with a significant increase in group A. Highly significant statistical differences $(P<0.001)$ were observed in the count of neutrophils, total red blood cells, hemoglobin, and hematocrit in group A as compared to group B. No significant differences were identified in the monocytic count and platelet count. The results of the hematological assessment are shown in Table 5. The pathology examination following bone marrow and sternum analysis revealed that in comparison with group B, the mice which received daily iv Tween ${ }^{\circledR}$ 20-GNPs had increased megakaryopoiesis (Figure 6) with a number of 53.40 \pm 2.293 megakaryocytes/five high-power fields as opposed to the

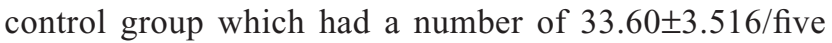
high-power fields (Table 6 and Figure 7). In Figure 6A and $\mathrm{B}$ (left), we have shown at different magnifications the increased megakaryopoiesis, as opposed to the control group (Figure 6C and D, right). No bone marrow fibrosis was identified.

Even if it was not an initial objective of our study, liver samples were also harvested for histological processing due to their obvious hypertrophy and greenish-like appearance, which macroscopically indicated cholestasis. This phenomenon was observed in all animals from the experimental group but in none from the control group. The macroscopic 
Table 4 Body weight of the experimental and control group

\begin{tabular}{|c|c|c|c|c|c|c|}
\hline \multirow[t]{2}{*}{ Day } & \multicolumn{2}{|c|}{ Group A (experimental) } & \multicolumn{2}{|c|}{ Group B (control) } & \multirow[t]{2}{*}{$t$} & \multirow[t]{2}{*}{$P$-value } \\
\hline & Mean \pm SEM & SD & Mean \pm SEM & SD & & \\
\hline I & $27.36 \pm 0.3377$ & 1.120 & $28.37 \pm 0.2630$ & 0.744 & 1.287 & $>0.05$ \\
\hline 2 & $29.18 \pm 0.5849$ & 1.940 & $29.87 \pm 0.3503$ & 0.991 & 0.882 & $>0.05$ \\
\hline 3 & $29.81 \pm 0.6152$ & 2.040 & $30.37 \pm 0.1829$ & 0.517 & 0.708 & $>0.05$ \\
\hline 4 & $29.18 \pm 0.4827$ & 1.601 & $30.62 \pm 0.2630$ & 0.744 & 1.837 & $>0.05$ \\
\hline 5 & $29.00 \pm 0.5300$ & 1.758 & $30.25 \pm 0.4531$ & 1.281 & 1.475 & $>0.05$ \\
\hline 6 & $29.00 \pm 0.5877$ & 1.949 & $30.12 \pm 0.3503$ & 0.991 & 1.432 & $>0.05$ \\
\hline 7 & $29.8 \mathrm{I} \pm 0.50 \mathrm{I} 2$ & 1.662 & $30.12 \pm 0.4794$ & 1.356 & 0.390 & $>0.05$ \\
\hline 8 & $29.18 \pm 0.5190$ & 1.721 & $29.75 \pm 0.3659$ & 1.035 & 0.723 & $>0.05$ \\
\hline 9 & $30.00 \pm 0.5045$ & 1.673 & $29.75 \pm 0.6196$ & 1.752 & 0.318 & $>0.05$ \\
\hline 10 & $30.09 \pm 0.5126$ & 1.700 & $30.00 \pm 0.5345$ & 1.511 & 0.115 & $>0.05$ \\
\hline II & $30.09 \pm 0.5633$ & 1.868 & $30.12 \pm 0.3980$ & 1.125 & 0.043 & $>0.05$ \\
\hline 12 & $30.72 \pm 0.4490$ & 1.489 & $30.25 \pm 0.4118$ & 1.164 & 0.607 & $>0.05$ \\
\hline 13 & $31.54 \pm 0.5110$ & 1.694 & $30.00 \pm 0.6267$ & 1.772 & 1.967 & $>0.05$ \\
\hline 14 & $31.45 \pm 0.5454$ & 1.809 & $30.12 \pm 0.7425$ & 2.100 & 1.692 & $>0.05$ \\
\hline 15 & $31.27 \pm 0.6043$ & 2.004 & $30.12 \pm 0.9531$ & 2.695 & $1.46 \mid$ & $>0.05$ \\
\hline 16 & $31.45 \pm 0.5285$ & 1.752 & $30.37 \pm 0.9624$ & 2.722 & 1.374 & $>0.05$ \\
\hline 17 & $32.18 \pm 0.5012$ & 1.662 & $31.00 \pm 0.8017$ & 2.267 & 1.504 & $>0.05$ \\
\hline 18 & $32.45 \pm 0.4929$ & 1.634 & $30.62 \pm 0.7303$ & 2.065 & 2.329 & $>0.05$ \\
\hline 19 & $32.8 \mathrm{I} \pm 0.4225$ & 1.401 & $30.62 \pm 0.7303$ & 2.065 & 2.791 & $>0.05$ \\
\hline 20 & $33.00 \pm 0.3813$ & 1.264 & $31.00 \pm 0.7559$ & 2.138 & 2.546 & $>0.05$ \\
\hline 21 & $33.27 \pm 0.4066$ & 1.348 & $31.50 \pm 0.707 \mid$ & 2.000 & 2.256 & $>0.05$ \\
\hline
\end{tabular}

Abbreviations: SEM, standard error of the mean; SD, standard deviation.

appearance of the liver suggested hepatic damage. The liver enzymes were increased in group A as opposed to group B, and in the case of bilirubin, the values were even exceeding the standard physiological values (Table 7). Figure $8 \mathrm{~A}$ and $\mathrm{B}$ shows a standard hematoxylin-eosin stain of the liver samples.
A moderate lymphoplasmocytic inflammatory infiltrate can be observed that extends to the portal space of the liver with a minimal periportal invasion. The samples showed minimal cholestasis alterations, and several hepatocytes expressed a brownish yellow pigment in their cytoplasm, and others

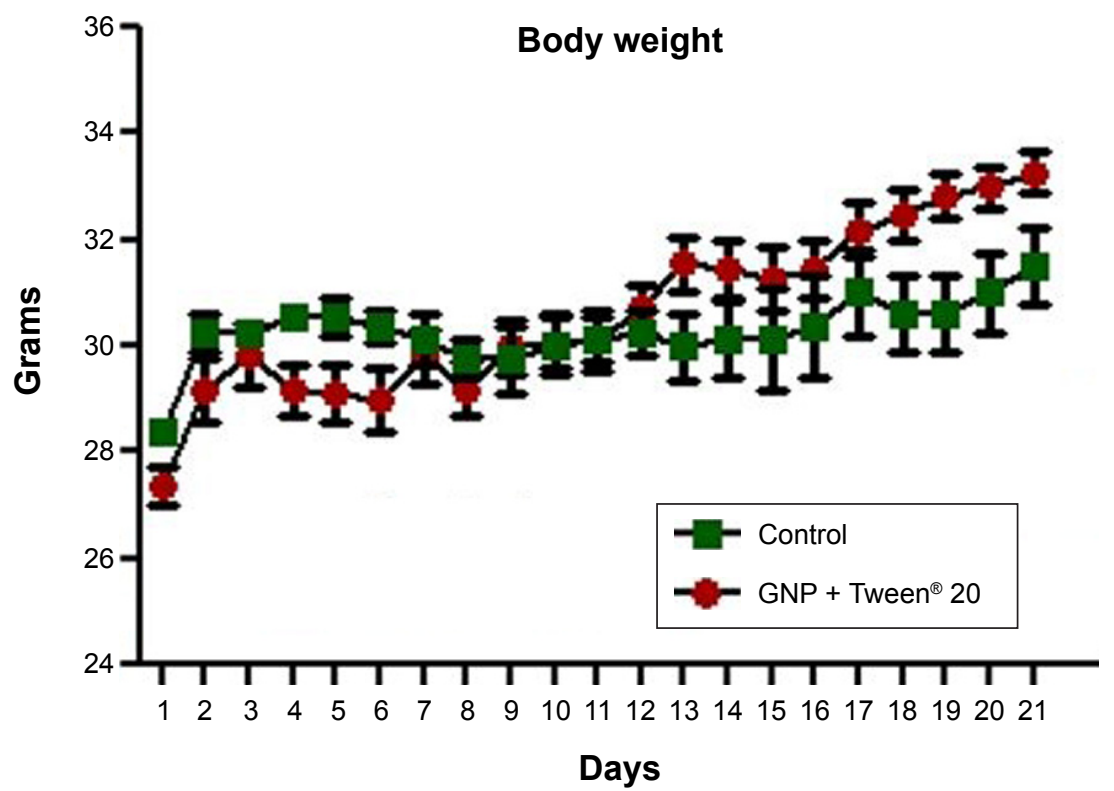

Figure 5 Body weight evaluation throughout the period of sub-chronic administration of Tween ${ }^{\circledR} 20-$ GNPs. Abbreviation: GNPs, gold nanoparticles. 
Table 5 Hematological assessment of the chronic toxicity study

\begin{tabular}{|c|c|c|c|c|c|c|}
\hline \multirow{2}{*}{$\begin{array}{l}\text { Hematological } \\
\text { parameter }\end{array}$} & \multirow{2}{*}{$\begin{array}{l}\text { Physiological } \\
\text { values }\end{array}$} & \multicolumn{2}{|c|}{ Group A (experimental) } & \multicolumn{2}{|c|}{ Group B (control) } & \multirow[t]{2}{*}{$P$-value } \\
\hline & & Mean \pm SEM & SD & Mean \pm SEM & SD & \\
\hline WBCs $\left(10^{9} / \mathrm{L}\right)$ & $6.0-15.0$ & $4.723 \pm 0.457 \mid$ & 1.120 & $3.557 \pm 0.1991$ & 0.4877 & $0.04 I 4 *$ \\
\hline Lymphocytes (I0\%/L) & $3.4-7.44$ & $3.327 \pm 0.3589$ & 0.8792 & $2.362 \pm 0.1329$ & 0.3255 & $0.0303 *$ \\
\hline Monocytes $\left(10^{9} / \mathrm{L}\right)$ & $0.0-0.6$ & $0.1633 \pm 0.05004$ & 0.1226 & $0.1433 \pm 0.03018$ & 0.07394 & 0.7393 \\
\hline Neutrophils $\left(10^{9} / \mathrm{L}\right)$ & $0.4-2.0$ & $1.168 \pm 0.1161$ & 0.2843 & $0.5600 \pm 0.07412$ & 0.1815 & $0.0013 * *$ \\
\hline $\operatorname{RBCs}\left(10^{12} / \mathrm{L}\right)$ & $7.00-12.0$ & $9.796 \pm 0.5078$ & 1.344 & $7.171 \pm 0.2300$ & 0.6085 & $0.0005^{* * *}$ \\
\hline $\mathrm{Hb}(\mathrm{g} / \mathrm{dL})$ & $10.0-16.0$ & $12.85 \pm 0.8277$ & 2.028 & $9.617 \pm 0.3240$ & 0.7935 & $0.0046 * *$ \\
\hline НCT (\%) & $35.0-45.0$ & $41.20 \pm 3.133$ & 7.674 & $28.50 \pm 1.217$ & 2.981 & $0.0036 * *$ \\
\hline Platelets ( $\left.10^{9} / \mathrm{L}\right)$ & $200-450$ & $304.2 \pm 6.760$ & 16.56 & $283.2 \pm 10.38$ & 25.44 & 0.1210 \\
\hline
\end{tabular}

Note: *,**,*** represent the degree of statistical significance.

Abbreviations: SEM, standard error of the mean; SD, standard deviation; WBCs, white blood cells; RBCs, red blood cells; Hb, hemoglobin; HCT, hematocrit.

expressed two nuclei or glycogenated nuclei. Figure $8 \mathrm{C}$ shows a Masson's trichrome stain for collagen in which a mild liver fibrosis in some of the portal spaces can be seen, with the tendency of progression to the periportal spaces with fine and short fibrous tissue septa. Figure 8D shows a Gomori stain that highlights the preservation of the normal hepatic lobule architecture.
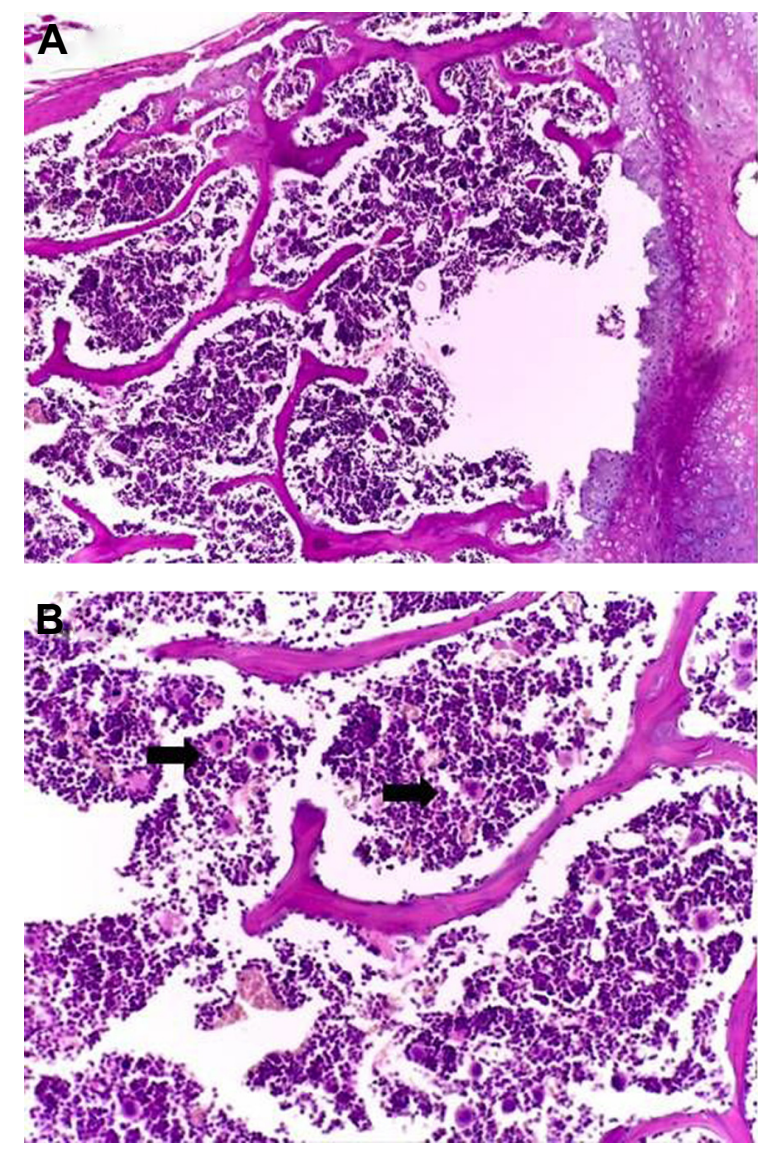

\section{Organ distribution of $\mathrm{Au}$}

In all animals from group $\mathrm{A}$, elemental Au was detected in all the harvested organs except the brains, after the 21-day period of Tween ${ }^{\circledR} 20$-GNPs iv administration, in quantities ranging from 333 to $8,378 \mathrm{ng} / \mathrm{g}$. The liver and the bladder had the highest concentrations of $\mathrm{Au}$, followed by the lungs, spleen, heart, and kidneys. High concentrations
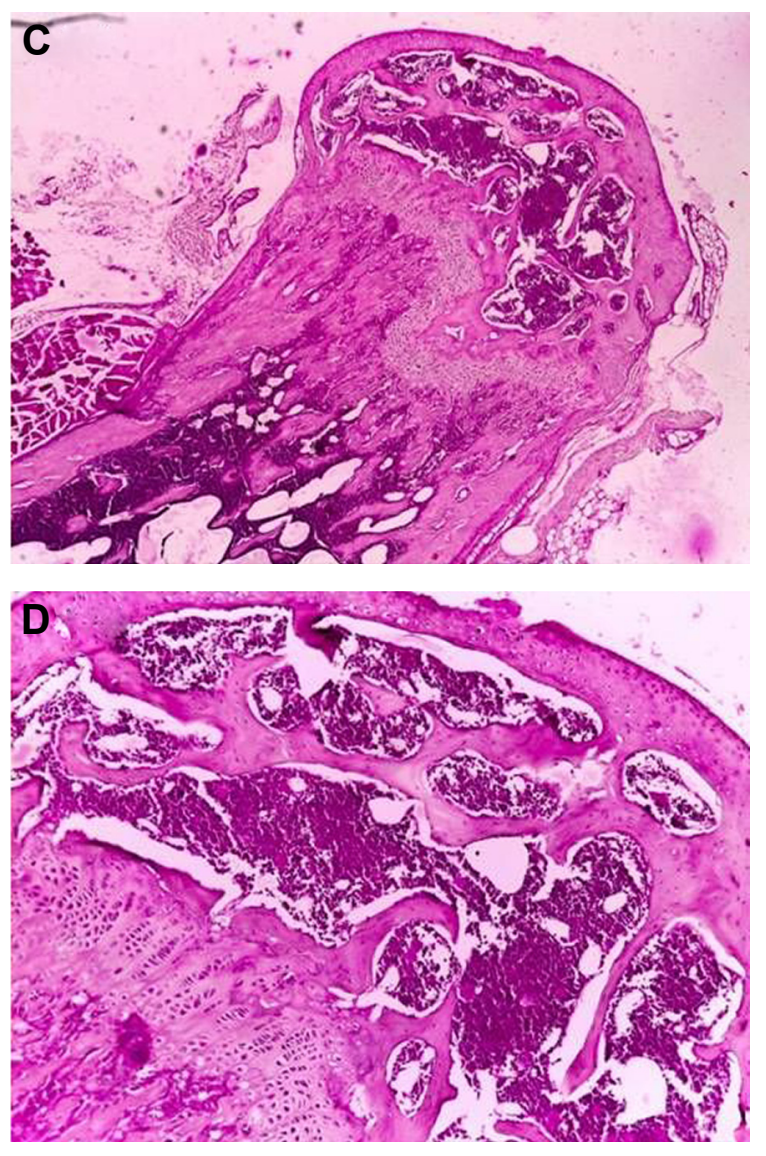

Figure 6 Pathology examination of the bone marrow.

Notes: Pathology examination of the bone marrow of the mice treated with Tween ${ }^{\circledR} 20-G N P s(\mathbf{A}$ and $\mathbf{B})$ and of the control group $(\mathbf{C}$ and $\mathbf{D})$. In $(\mathbf{A})$ and $(\mathbf{C}), \times 4$ magnification, and in (B) and (D), $\times 20$ magnification. The black arrows show the megakaryocytes.

Abbreviation: GNPs, gold nanoparticles. 
Table 6 Reactive or increased magakaryocyte count for animals treated with GNP-Tween

\begin{tabular}{lllllll}
\hline & \multicolumn{2}{l}{ Group A (experimental) } & & \multicolumn{2}{l}{ Group B (control) } & \multicolumn{2}{c}{ P-value } \\
\cline { 2 - 3 } \cline { 5 - 6 } & Mean \pm SEM & SD & & Mean \pm SEM & SD & \\
\hline Number of megakaryocytes/5 HPFs & $53.40 \pm 2.293$ & 5.128 & & $33.60 \pm 3.516$ & $\mathbf{0 . 0 0 1 5}$ \\
\hline
\end{tabular}

Note: Data in bold indicates statistical significance.

Abbreviations: SEM, standard error of the mean; SD, standard deviation; HPFs, high-power fields.

of elemental Au were also detected in all the harvested femurs. No Au was detected in the tissues and organs harvested from the individuals from the control group. The detailed results of the ICP-MS Au measurements are presented in Table 8.

\section{Discussion}

Nanotechnology is of major interest in clinical hematology and oncology for both therapy and diagnosis because of unique features that include self-assembly or the ability to make use of the enhanced permeability and retention effects most malignancies have as a consequence of a leaky neoangiogenesis and the absence of functional lymphatic system. Nanostructures can be designed to carry useful payloads that include low-molecular weight chemotherapeutic agents or contrast substances. ${ }^{20}$ Moreover, the newly formed structures are able to rapidly detect cancer cells, load multiple anticancer active substances on their surface, and deliver the drugs rapidly to the target cell. ${ }^{21}$ In the current research, we aimed to investigate the biodistribution of GNPs capped with Tween ${ }^{\circledR} 20$ in vivo, as Tween ${ }^{\circledR} 20$ is one of the most efficient coating systems of colloidal $\mathrm{Au}$ which is a precursor for conjugation with various drugs used in the clinic..$^{22,23}$ Moreover, Tween ${ }^{\circledR} 20$ is uptaken preferentially by the reticuloendothelial system, ${ }^{24}$ also known as the mononuclear phagocyte system. The reticuloendothelial

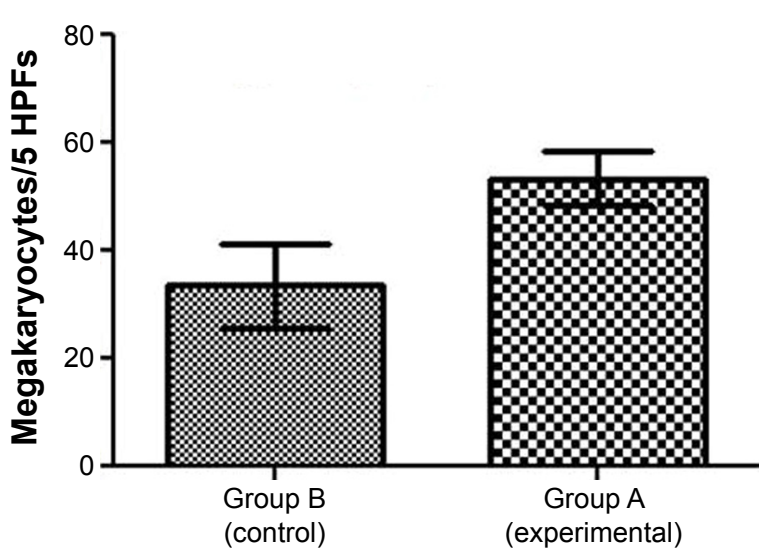

Figure 7 Increased megakaryopoiesis in the mice treated with Tween ${ }^{\circledast}$ 20-GNPs. Note: Megakaryocyte count is shown.

Abbreviations: GNPs, gold nanoparticles; HPFs, high-power fields. system holds important immune functions and is located in reticular connective tissues of the spleen, lymph nodes, bone marrow, and liver. ${ }^{25}$ The accumulation of Tween ${ }^{\circledR} 20$ in such tissues allows the targeted delivery of various antileukemic active drugs in the very tissue where leukemic clones appear, develop, and relapse: the bone marrow, lymph nodes, and spleen.

In our experiments, the body weight of both groups increased steadily over the course of the 21 days, with no statistical significance being identified in the experimental group as compared to the control group. At first sight, this might suggest the lack of toxicity of Tween ${ }^{\circledR} 20$-GNPs. The altered blood tests are vaguely conclusive at this point, and further studies are required in order to assess whether the sub-chronic administration of our bioconjugate has any effect on hematopoiesis or not. The total WBC count showed a decrease in both groups, below the physiological value. This may be an effect of the daily isoflurane use when performing the iv injections, as isoflurane has been shown to have a pronounced leukopenic effect in mice. ${ }^{26}$ Still, the WBC count in the experimental group was higher as opposed to the control group, as were all the assessed parameters in the experimental group, a phenomena which could indicate increased reactive hematopoiesis, as also confirmed by other studies, ${ }^{27}$ and could confirm the data obtained by the pathological examination of the bone marrow. The elevated liver enzymes and bilirubin suggested liver damage, which was confirmed by the pathological examination of the liver samples. Our data show that this conjugate is found in the bladder in high quantities, a proof that most of the bioconjugates are safely excreted through urine. Elemental Au was not detected in the brains of the experimental animals, which suggests that Tween ${ }^{\circledR} 20$-GNPs cannot pass the blood-brain barrier at a size of $15 \mathrm{~nm}$, and is of great clinical importance as it does not affect the very sensitive nervous tissue. Au was shown to accumulate in the hematopoietic bone tissue, with significant side effects such as leucopoiesis and megakaryopoiesis. Still, at this point, it is uncertain whether the mice were reactive to $\mathrm{Au}$ as it is a foreign substance or whether the side effects observed were a precursor condition of a more 
Table 7 Liver toxicity assessment

\begin{tabular}{|c|c|c|c|c|c|c|}
\hline \multirow{2}{*}{$\begin{array}{l}\text { Biochemical } \\
\text { parameter }\end{array}$} & \multirow{2}{*}{$\begin{array}{l}\text { Physiological } \\
\text { values }\end{array}$} & \multicolumn{2}{|c|}{ Group A (experimental) } & \multicolumn{2}{|c|}{ Group B (control) } & \multirow[t]{2}{*}{$P$-value } \\
\hline & & Mean \pm SEM & SD & Mean \pm SEM & SD & \\
\hline AST (U/L) & $54-298$ & $111.1 \pm 7.589$ & 18.59 & $51.97 \pm 3.743$ & 9.168 & $<0.0001$ \\
\hline ALT $(U / L)$ & $17-77$ & $71.11 \pm 6.917$ & 16.94 & $33.96 \pm 2.742$ & 6.717 & 0.0005 \\
\hline Bilirubin $(\mathrm{mg} / \mathrm{dL})$ & $0.0-0.9$ & $1.350 \pm 0.06708$ & 0.1643 & $0.1833 \pm 0.04014$ & 0.09832 & $<0.0001$ \\
\hline
\end{tabular}

Note: Data in bold indicates statistical significance.

Abbreviations: SEM, standard error of the mean; SD, standard deviation; AST, aspartate aminotransferase; ALT, alanine aminotransferase.

severe hematological condition. What is certain is that at these concentrations and when exposed to via sub-chronic systemic administration, Au is hepatotoxic. The data presented in the current paper showed some important hepatic lesions like interface hepatitis and a mild fibrosis, which would suggest hepatotoxic phenomena. Moreover, the fact that glycogenated nuclei were identified raises some issues as these types of nuclei are a common finding in liver biopsy specimens from patients presenting serious clinical disorders, most commonly obese or diabetic patients or patients with nonalcoholic fatty liver disease. ${ }^{28}$ Our results are urging the need for further studies in order to achieve better in vivo compliance and exploit the immense potential of GNPs in cancer pharmacology.

\section{Conclusion}

Nanotechnology is very important in modern clinical hematology and oncology for both therapy and diagnosis.
Various nanostructures can be designed to carry useful payloads that include low-molecular weight chemotherapeutic agents or contrast substances. In the current paper, we describe the bone marrow toxicity by GNPs conjugated with Tween ${ }^{\circledR} 20$ and its tropism for the organs with an enriched reticuloendothelial system because Tween ${ }^{\circledR} 20$ is a perfect coating for GNPs and allows a further bioconjugation with various antileukemic drugs. As we have proven that GNPs coated with Tween ${ }^{\circledR} 20$ are perfect delivery agents for antileukemic drugs, the assessment of their toxicity is crucial before we move on to the next step and initiate a preclinical model of the disease.

\section{Acknowledgment}

This work was supported by the international grant Romania-European Economical Space (Norway) 2015-2016 (contract 1/25.06.2015), awarded to Ciprian Tomuleasa and Sanda Boca.
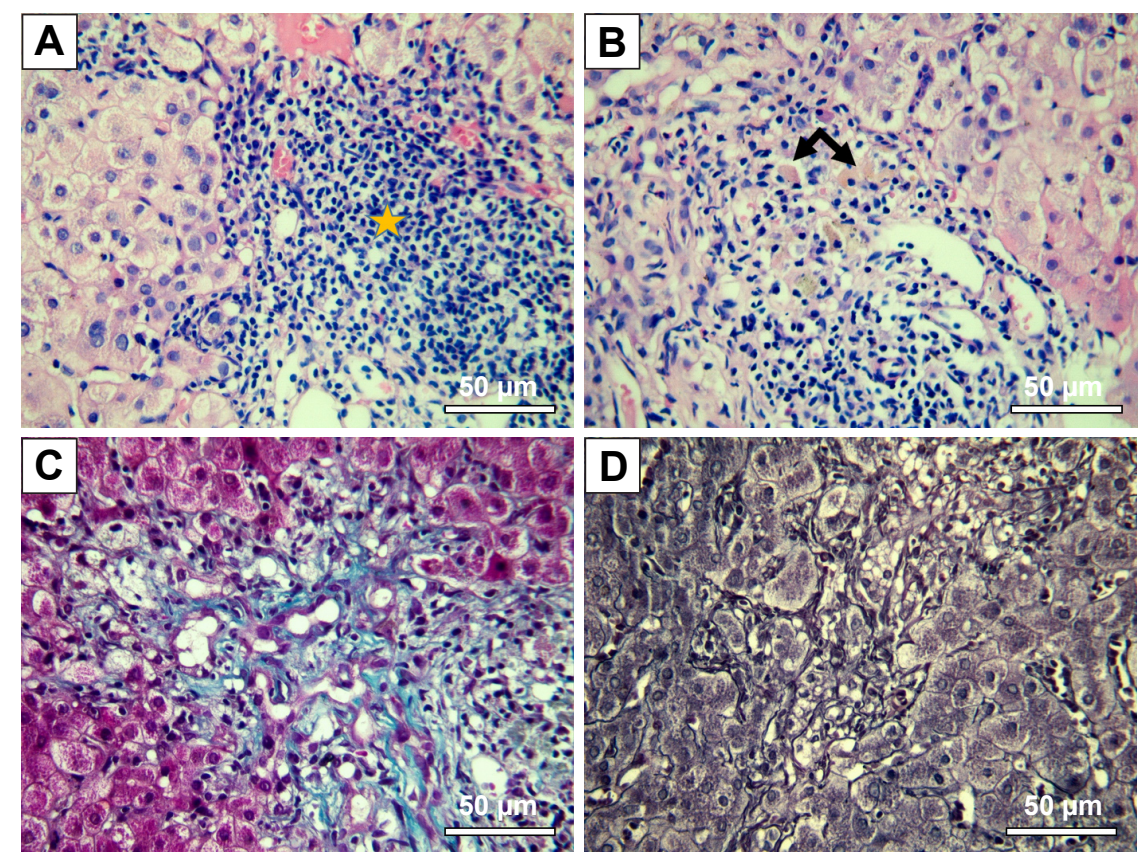

Figure 8 Interface hepatitis-like lesions and mild fibrosis in mice treated with Tween 20-GNPs.

Notes: Pathology images are shown. (A) HE stain, massive lymphoplasmacytic infiltrate in the liver tissue (star) with interface hepatitis-like lesions. (B) HE stain, binucleated (left arrow) and glycogenated (right arrow) nuclei. (C) Masson's-Trichrome staining, mild liver fibrosis. (D) Gomori stain - normal liver architecture.

Abbreviations: GNPs, gold nanoparticles; HE, Hematoxylin-Eosin stain. 
Table 8 Organ distribution of the gold nanoparticles

\begin{tabular}{lll}
\hline Tissue/organ & \multicolumn{2}{c}{ Concentration of elemental Au (ng/g) } \\
\cline { 2 - 3 } & Mean \pm SEM & SD \\
\hline Brain & 0 & 0 \\
Heart & $811.0 \pm 6.507$ & $1 \mathrm{I} .27$ \\
Lungs & $\mathrm{I}, 544 \pm 103.7$ & 179.6 \\
Liver & $8,325 \pm 40.43$ & 70.02 \\
Spleen & $852.6 \pm 4.240$ & 7.345 \\
Kidneys & $230.2 \pm 9.540$ & 16.52 \\
Bladder & $6,818 \pm 136.5$ & 236.5 \\
Femur & $525.9 \pm 57.49$ & 128.5 \\
\hline
\end{tabular}

Abbreviations: SEM, standard error of the mean; SD, standard deviation.

\section{Disclosure}

The authors report no conflicts of interest in this work.

\section{References}

1. Tomuleasa C, Braicu C, Irimie A, Craciun L, Berindan-Neagoe I. Nanopharmacology in translational hematology and oncology. Int J Nanomedicine. 2014;9:3465-3479.

2. Orza A, Soriţău O, Tomuleasa C, et al. Reversing chemoresistance of malignant glioma stem cells using gold nanoparticles. Int J Nanomedicine. 2013;8:689-702.

3. Tomuleasa C, Soritau O, Orza A, et al. Gold nanoparticles conjugated with cisplatin/doxorubicin/capecitabine lower the chemoresistance of hepatocellular carcinoma-derived cancer cells. J Gastrointestin Liver Dis. 2012;21(2):187-196.

4. Li L, Masica D, Ishida M, et al. Human bile contains microRNA-laden extracellular vesicles that can be used for cholangiocarcinoma diagnosis. Hepatology. 2014;60(3):896-907.

5. Selvamuthukumar S, Velmurugan R. Nanostructured lipid carriers: a potential drug carrier for cancer chemotherapy. Lipids Health Dis. 2012;11:159.

6. Singh S, Sharma A, Robertson GP. Realizing the clinical potential of cancer nanotechnology by minimizing toxicologic and targeted delivery concerns. Cancer Res. 2012;72(22):5663-5668.

7. Brie IC, Soritau O, Dirzu N, et al. Comparative in vitro study regarding the biocompatibility of titanium-base composites infiltrated with hydroxyapatite or silicatitanate. J Biol Eng. 2014;8:14.

8. Leonard RC, Williams S, Tulpule A, Levine AM, Oliveros S. Improving the therapeutic index of anthracycline chemotherapy: focus on liposomal doxorubicin (Myocet). Breast. 2009;18(4):218-224.

9. Petrelli F, Borgonovo K, Barni S. Targeted delivery for breast cancer therapy: the history of nanoparticle-albumin-bound paclitaxel. Expert Opin Pharmacother. 2010;11(8):1413-1432.

10. Singh R, Mukhopadhyay K. Survival analysis in clinical trials: basics and must know areas. Perspect Clin Res. 2011;2(4):145-148.

11. Simon T, Tomuleasa C, Bojan A, Berindan-Neagoe I, Boca S, Astilean S. Design of FLT3 inhibitor - gold nanoparticle conjugates as potential therapeutic agents for the treatment of acute myeloid leukemia. Nanoscale Res Lett. 2015;10(1):466.
12. Suarasan S, Simon T, Boca S, Tomuleasa C, Astilean S. Gelatin coated gold nanoparticles as carriers of FLT3 inhibitors for acute myeloid leukemia treatment. Chem Biol Drug Des. 2016;87(6):927-935.

13. Petrushev B, Boca S, Simon T, et al. Gold nanoparticles enhance the effect of tyrosine kinase inhibitors in acute myeloid leukemia therapy. Int J Nanomedicine. 2016;11:641-660.

14. Janice Duy J, Connell LB, Eck W, Collins SD, Smith RL. Preparation of surfactant-stabilized gold nanoparticle-peptide nucleic acid conjugates. J Nanopart Res. 2010;12(7):2363-2369.

15. Chirteş F, Trombitas V, Vlad D, Tabaran F, Berce C, Albu S. Efficiency of cryotherapy in avoiding myringotomy closure in rats. Indian J Otolaryngol Head Neck Surg. 2015;67(1):68-71.

16. Rotaru H, Armencea G, Spîrchez D, et al. In vivo behavior of surface modified Ti6Al7Nb alloys used in selective laser melting for custom-made implants. A preliminary study. Rom J Morphol Embryol. 2013;54(3 Suppl):791-796.

17. McGrath JC, McLachlan EM, Zeller R. Transparency in research involving animals: the basel declaration and new principles for reporting research in BJP manuscripts. Br J Pharmacol. 2015;172(10): 2427-2432.

18. Yardeni T, Eckhaus M, Morris HD, Huizing M, Hoogstraten-Miller S. Retro-orbital injections in mice. Lab Anim (NY). 2011;40(5): $155-160$.

19. Sadauskas E, Jacobsen NR, Danscher G, et al. Biodistribution of gold nanoparticles in mouse lung following intratracheal instillation. Chem Cent J. 2009;3:16.

20. Osminkina LA, Sivakov VA, Mysov GA, et al. Nanoparticles prepared from porous silicon nanowires for bio-imaging and sonodynamic therapy. Nanoscale Res Lett. 2014;9(1):463.

21. Tamarov KP, Osminkina LA, Zinovyev SV, et al. Radio frequency radiation-induced hyperthermia using Si nanoparticle-based sensitizers for mild cancer therapy. Sci Rep. 2014;4:7034.

22. Shih YC, Ke CY, Yu CJ, Lu CY, Tseng WL. Combined tween 20stabilized gold nanoparticles and reduced graphite oxide-Fe3O4 nanoparticle composites for rapid and efficient removal of mercury species from a complex matrix. ACS Appl Mater Interfaces. 2014; 6(20):17437-17445.

23. Duxfield L, Sultana R, Wang R, et al. Development of gatifloxacinloaded cationic polymeric nanoparticles for ocular drug delivery. Pharm Dev Technol. 2016;21(2):172-179.

24. Kudgus RA, Walden CA, McGovern RM, Reid JM, Robertson JD, Mukherjee P. Tuning pharmacokinetics and biodistribution of a targeted drug delivery system through incorporation of a passive targeting component. Sci Rep. 2014;4:5669.

25. Johnston RB Jr. Current concepts: immunology. Monocytes and macrophages. N Engl J Med. 1988;318(12):747-752.

26. Gargiulo S, Greco A, Gramanzini M, et al. Mice anesthesia, analgesia, and care, Part I: anesthetic considerations in preclinical research. ILARJ. 2012;53(1):E55-E69.

27. Ghosh S, Sengupta J, Datta P, Gomes A. Hematopoietic and antioxidant activities of gold nanoparticles synthesized by aqueous extract of fenugreek (Trigonella foenum-graecum) seed. Adv Sci Eng Med. 2014;6(5):546-552.

28. Wang MX, Morgan T, Lungo W, Wang L, Sze GZ, French SW. "Piecemeal" necrosis: renamed troxis necrosis. Exp Mol Pathol. 2001; 71(2):137-146.
International Journal of Nanomedicine

\section{Publish your work in this journal}

The International Journal of Nanomedicine is an international, peerreviewed journal focusing on the application of nanotechnology in diagnostics, therapeutics, and drug delivery systems throughout the biomedical field. This journal is indexed on PubMed Central, MedLine, CAS, SciSearch ${ }^{\circledR}$, Current Contents ${ }^{\circledR} /$ Clinical Medicine,

\section{Dovepress}

Journal Citation Reports/Science Edition, EMBase, Scopus and the Elsevier Bibliographic databases. The manuscript management system is completely online and includes a very quick and fair peer-review system, which is all easy to use. Visit http://www.dovepress.com/ testimonials.php to read real quotes from published authors. 